\title{
The Relationship between Salary Packages and Employee's Subjective Well-being: Evidence from Service-based SMEs in Pakistan
}

\author{
Nimra Ali Khokher ${ }^{1}$, Abdul Raziq ${ }^{1 *}$
}

\begin{abstract}
An excellent package of salary plays very important role in the management of the talented people of the organization because such packages bring positivity in the feelings, behaviors and in the satisfaction of the people. The objective of this study is to test the hypotheses to investigate the relationship between salary packages and employee's subjective well-being. The study employed a quantitative methodology. Data were collected through a self-administered survey questionnaire. The questionnaire was adapted from a previous validated survey. The target population consisted of SMEs operating in the city of Quetta, Pakistan. Convenience sampling was applied to collect data from service-sector SMEs. A total of 486 questionnaires were distributed. Of these, 380 were received. However, 349 questionnaires were finally considered as useable. The results of correlation and regression analyses indicate that salary packages have significant positive impact upon employee's subjective well-being. Our study indicates that when an organization implement practice of excellent and attractive salary packages then such practices develop a realization of trust among the employees which bring positivity in their feelings and behaviors and this will develop their belonging and satisfaction towards the organization. This study also suggests that the top management should continuously monitor the structure of salary in the organization and devise such kind of salary structure which gives recognition to the competent talent of the organization.
\end{abstract}

Keywords: Salary Packages, Employee's SWB, Small and Medium Sized Enterprise (SMEs).

\section{Introduction}

An excellent package of salary plays a very important role in the management of the talented people of the organization because when attractive and competitive salary packages are given to the employees, such employees become more committed to the organization (Lockwood \& Walton, 2008). According to Kirkland (2009) manners of

https://doi.org/10.30537/sijmb.v4i1.104

${ }^{1}$ Faculty of Management Sciences, Baluchistan University of Information Technology, Engineering and Management Sciences, Quetta, Pakistan

* Corresponding Author: araziq85@yahoo.com 
Nimra Ali Khokher \& Abdul Raziq / The Relationship between Salary Packages and Employee's Subjective Well-

administering excellent salary packages in an organization are highly concerned with either promoting the talent management process in an organization or discouraging it. He further stated that nowadays organizations are highly concerned in acquiring and selecting new talent and in retaining existing talent and focus more on the retention of competent talent.

In this way, excellent salary packages in an organization play a key role by retaining and managing the talented and valued staff (Chikumbi, 2011). When organizations give excellent salary packages for the management of their talented and valued staff, such packages bring positivity in the feelings, behaviors and in the satisfaction of such talented staff, which in turn influence their long term retention in the organization.

Similarly, it is true that when in an organization, deserving and talented staff are given rewards, such rewards will appreciate them to continue their desired behaviors in the organization (Locke , 1990). That's why it is essential for an organization to ensure that the compensations and rewards which are given to the talented staff should be valuable for the employees of the organization. Thus, for the purpose of having an effective salary structure organization should continuously monitor the structure of salary in the industry and devise such kind of salary structure which recognize the competent talent of the organization (Chikumbi, 2011).

About SWB McGillivray and Clarke (2006) specified that "SWB involves a multidimensional evaluation of life, including cognitive judgments of life satisfaction and affective evaluations of emotions and moods" (p. 4). In this way, SWB is the combination of positive and negative affection and life satisfaction (Shmotkin, 1998). Here positive affection means pleasant emotions or feeling like happiness or joy and negative affection means unpleasant emotions or feelings like sadness or anger. Moreover, prior studies on SWB mentioned that it has two parts such as, cognitive component and affective component (Westaway \& Maluka, 2005). According to BenZur (2003) cognitive components are the judgmental components which represent life satisfaction whereas; affective components are the emotional components which represent positive or negative affections or emotions. In this way positive effect represent positive emotions and negative effects represents dissatisfaction and distress. This show that positive effects are positive emotions or positive feelings or one can say happiness, however negative affect are negative emotions or negative feelings or one can say sadness, anxiety or distress. This indicates that SWB is a kind of cognitive and effective evaluation of the people which is made to know how with their life, they are happy and satisfied (Page, 2005).

It has been observed from prior studies that not much work has been found on the impact of salary packages upon SWB of the employees. For instance, the studies of (Chikumbi, 2011; Collings \& Mellahi, 2009; Dhulla, 2013) focused only the impact of

Sukkur IBA Journal of Management and Business | Volume 4 No. 1 January - June 2017 @ Sukkur IBA University 
Nimra Ali Khokher \& Abdul Raziq / The Relationship between Salary Packages and Employee's Subjective Well-

employee empowerment upon employee's satisfaction or upon competitive advantage or covered only the effective components such as, positive emotions, feeling, moods and not covered cognitive components.

While, SWB covers both cognitive and effective parts of employees. Therefore, this study has addressed this gap by examining the impact of salary packages upon employee's SWB. Moreover, Prior studies have also shown that there is a lack of research in the field of salary packages and employee's SWB in SMEs. This leads to lack of knowledge about the phenomena in the context of SMEs. Similarly, there is lack of awareness regarding these phenomena particularly in the context of Baluchistan, Pakistan. Therefore, such problem statement gives rise the need to be resolved which has been done by this study.

Prior literature indicates that SMEs have become an important part of the economies of the industries (Eikebrokk \& Olsen, 2007). In every country, SMEs have key roles in developing the economic conditions (Calice, Chando, \& Sekioua, 2012). However, the spectrum of the definitions of SMEs is broad as different firms and different countries use different guidelines in defining SMEs, mostly based on the number of employees, revenues or assets (Bouri et al., 2011). For example, "Egypt defines SMEs as having more than 5 and fewer than 50 employees Vietnam considers SMEs to have between 10 and 300 employees the World Bank defines SMEs as those enterprises with a maximum of 300 employees \$15 million in annual revenue and \$15 million in assets and Inter-American Development Bank meanwhile describes SMEs as having a maximum of 100 employees and less than $\$ 3$ million in revenue" (Bouri et al., 2011).

Like other countries, different institutions in Pakistan use different definition of SMEs. For example, SMEDA defines SME based upon the number of employees (up to 250), paid up capital (up to Rs. 25) and annual sales (up to Rs. 250), the SME bank uses only total number of assets as the criterion, PBS takes into consideration only the number of employees, Whereas, SBP's definition of a SME is based on the nature of the business, number of employees, amount of capital employed and net sales value per annum (Raziq \& Shaikh, 2015).

Moreover, much more work has been done on large organization regarding salary packages. However, studies regarding small and medium-sized organization with special focus on salary packages and employee's SWB are lacking. Therefore, this study has addressed the gap by examining the impact of salary packages upon employee's SWB in SMEs of Baluchistan, Pakistan.

The outcomes of this study will enhance the knowledge about the importance of excellent salary packages in SMEs and its impact upon the SWB of their employees. It is a fact that if the practice of excellent salary packages is successfully implemented,

Sukkur IBA Journal of Management and Business | Volume 4 No. 1 January - June 2017 @ Sukkur IBA University 
Nimra Ali Khokher \& Abdul Raziq / The Relationship between Salary Packages and Employee's Subjective Well-

then this will lead an organization towards competitive advantage, because successfully implementing this practice will enhanced the organizational productivity and enhance the overall motivation of the employees. Such motivated employees become innovative and effectively contribute to the firm (Chikumbi, 2011). Therefore, this study will give an addition to the literature by enhancing the knowledge and awareness about the importance of excellent salary packages and its impact upon employee's SWB particularly in the context of service based SMEs of Baluchistan, Pakistan.

\section{Theory and Hypothesis}

According to Kirkland (2009) ways of administering salary packages in an organization are highly concerned with either promoting the talent management process in an organization or discouraging it. Lockwood and Walton (2008), further added that an attractive package of salary plays a very important role in managing the people of the organization because when attractive and competitive salary packages are given to employees, employees become more committed to the organization. In this way, an excellent and attractive salary package brings positivity in the feelings, behaviors and in the satisfaction of such talented staff (Chikumbi, 2011).

Kirkland (2009), further stated that nowadays organizations are highly concerned in acquiring and selecting new talent and in retaining existing talent and focus more on the retention of competent talent. Therefore, an organization become successful in shaping positive attitudes and behaviors in their talented employees by giving them attractive packages of salary system. This will result in the retention of talented people in the organization (Lockwood \& Walton, 2008). It has also been observed that organization losing the talented staff are those who have unsatisfied employees with the salary structure of the organizations (Chikumbi, 2011). Therefore, an attractive salary package has the potential to increase the positive feelings and behaviors of the talented people of the organization (Kirkland, 2009).

Moreover, Coetsee (2011) suggested that top management of the organization should make struggle in order to motivates and encourage their talented people of the organization and then provide such recognition to the employees, which can appreciate the employees in order to perform well for the success of the organization. It is a fact that people give preference to only those organizations which have effective system for salary distribution (Chikumbi, 2011). It can also be said that an effective structure of salary package has the power to build up the behavioral aspects of the employees (Kirkland, 2009). Therefore, it seems to be very important for the organizations to set up such kind of salary structure which boosts the positive feelings, behaviors and satisfactions of the employees (Coetsee, 2011). He further explained the importance of the excellent salary packages that when these are given to the deserving talent, they are encouraged and satisfied, work hard and become motivated to their work. This

Sukkur IBA Journal of Management and Business | Volume 4 No. 1 January - June 2017 @ Sukkur IBA University 
Nimra Ali Khokher \& Abdul Raziq / The Relationship between Salary Packages and Employee's Subjective Well-

indicates that a valuable system of salary fosters the effective and cognitive aspects of employee's SWB.

Hence, SWB is the combination of positive and negative affection and life satisfaction (Shmotkin, 1998). Here positive affection means pleasant emotions or feeling like happiness or joy and negative affection means unpleasant emotions or feelings like sadness or anger. Similarly according to Diener (1994) SWB is "a broad category of phenomena that includes people's emotional responses, domain satisfactions, and global judgments of life satisfaction" (p. 277). In the same way, Diener (1994) mentioned that SWB has two important components such as, effective component which consists of the positive affection and cognitive component. Effective components measure the emotions and feelings of a person whereas, cognitive components measure that to what extent one's life is satisfied and goes according to his expectations (Van Hoorn, 2007).

This shows that SWB is a kind of cognitive and affective evaluation of the people which is made to know how with their life they are happy and satisfied (Page, 2005). It has been observed from the literature that salary packages have influence upon the multidimensional evaluation of life. While "SWB involves a multidimensional evaluation of life, including cognitive judgments of life satisfaction and effective evaluations of emotions and moods" (McGillivray \& Clarke, 2006). This study examines the influence of salary packages upon the SWB of the employees. Therefore, following hypotheses have been developed by this study.

H1: There is a significant positive relationship between salary packages and affective components of employee's subjective well-being.

H2: There is a significant positive relationship between salary packages and cognitive components of employee's subjective well-being.

\section{Methodology}

Sample

To test the hypotheses of this study, questionnaire survey was conducted in Quetta city of Pakistan. In this study, target population consists of SMEs operating in the city of Quetta because Quetta is the capital and largest city of the province of Baluchistan. Moreover, in the province of Baluchistan, Quetta city is considered as "center of commercial activities" and having "central and strategic position" (DDPQ, 2011). Being a capital city, Quetta has a vast chain of businesses, industries, markets, resources etc. as compared to other cities of Baluchistan. Moreover, due to limited access, time constraint and inconvenience this study has not targeted SMEs of other cities of Baluchistan.

Sukkur IBA Journal of Management and Business | Volume 4 No. 1 January - June 2017 @ Sukkur IBA University 
Nimra Ali Khokher \& Abdul Raziq / The Relationship between Salary Packages and Employee's Subjective Well-

Sampling technique for this study was a non-probability sampling method due to the fact that there is not a single database in Quetta city that is specifically designed for SMEs. Even Quetta Chamber of Commerce and Industry (QCCI) does not provide reliable and updated sampling frame about SMEs operating in Quetta city. The use of such nonprobability sampling method is also supported by Raziq and Shaikh (2015) in their study that there is no SME database available in Pakistan.

Service sectors employees of SMEs of Quetta city were sampled. This study has not targeted manufacturing based SMEs of Quetta city because as compared to other cities of Pakistan, Quetta city has lack of resources and polices in order to develop proper arrangements for manufacturing based SMEs. In this way, as compared to service based SMEs, very few manufacturing based SMEs are working in Quetta city which were not enough to provide sufficient data for this study. Therefore, this was not feasible to collect data from the manufacturing based SMEs of Quetta city.

\section{Data Collection}

First, for collecting data, telephonic calls were made to the heads/managers of service based SMEs in order to know whether particular organization is SMEs or not. After getting appointments from the heads/managers, a meeting was conducted with them. During the meeting, a permission letter from the researcher's university was presented to the heads/managers. This letter mentioned the details of the researcher as well as about the purpose of study and asking permission for data collection.

After getting permission, through a "self-administered questionnaires" data was collected. Such questionnaires were distributed to the employees of the services based SMEs operating in Quetta city. Each questionnaire was attached with an introduction page mentioning the complete details of researcher and study. It also allows the participants to give their participation "voluntary and can refuse to participate or stop at any time without any prejudice". It was also agreed that "participant's identity will therefore be treated as strictly confidential".

This study has distributed about 486 questionnaires to the employees of SMEs and has received 380 questionnaires. However, out of 380 questionnaires 349 questionnaires were finally considered as useable and 31 questionnaires were discarded because of having errors during the completion of the questionnaires.

After getting questionnaires, they were stored in a safe place. Supervisor and researcher were the only persons who had access to the filled questionnaires. All the results were only discussed with the supervisors.

\section{Measures}

Questionnaire: The Questionnaire for this study was adopted from the research study of (Chikumbi, 2011). The validity and reliability issues were addressed through factor analysis and Cronbach alpha. Subjective Well-being (SWB) can be measured by

Sukkur IBA Journal of Management and Business | Volume 4 No. 1 January - June 2017 @ Sukkur IBA University 
Nimra Ali Khokher \& Abdul Raziq / The Relationship between Salary Packages and Employee's Subjective Well-

effective components such as, positive or negative emotions and by cognitive components such as, life satisfaction. These two components of SWB are measured separately by using two different scales. Therefore, this study has also used these scales by adopting the questionnaire from the research study of (Jansen, 2008).

Effective components such as positive or negative emotions are measured by "Positive and Negative Effect Scale (PANES)". This scale has a list of emotions or feelings and the participants are requested to mention that to what extent they feel these emotions or feelings. This scale comprised 20 items in which 10 items "measured positive effect" and 10 items measured negative effect at five point Likert scale such as, "strongly disagree, disagree, uncertain, agree, strongly agree". While, cognitive component such as, life satisfaction is measured by "Satisfaction with Life Scale (SWLS)". This scale comprised 5 items at five "point Likert scale" such as, "strongly disagree, disagree, uncertain, agree, and strongly agree".

The content validity and reliability of the questionnaire was also addressed (see Table $2 \& 3$ ). For the purpose of determining the content validity of the questionnaire with respect to culture, norms and environment of the SMEs of Quetta city, we presented questionnaire to the SMEs experts and to the owners and managers of service based SMEs within Quetta city for getting their comments and feedbacks on the suitability of each item. After getting their comments and feedbacks, questionnaire was revised and redesigned in such a way that some irrelevant questions were removed. The language of some questions was also transformed in a way that it gave simple and easy meanings and understanding to the respondents. Reliability analysis indicated "Cronbach alpha coefficient" greater than 0.7 (see Table 3).

\section{Results}

\section{Composition of the Data}

Table 1 displays age and gender analysis of the participants. In this study out of 349 respondents, only $124(35 \%)$ were the females and $225(65 \%)$ were males who participated in this study. Similarly, about 154 (44\%) participants of the study were between 15-25 years of age, 123 (35\%) participants were between 26-35 years of age, $54(16 \%)$ participants were between 36-45 years of age, 11 (3\%) participants were between 46-55 years of age and about 7 (2\%) participants were between 56-above years of age. 
Nimra Ali Khokher \& Abdul Raziq / The Relationship between Salary Packages and Employee's Subjective Well-

Table 1: Composition of the Data $(n=349)$

\begin{tabular}{|c|c|c|c|c|}
\hline & \multicolumn{3}{|c|}{ Gender } & \multirow[b]{2}{*}{$\begin{array}{l}\text { Cumulative } \\
\text { Percent }\end{array}$} \\
\hline & Frequency & Percent & $\begin{array}{l}\text { Valid } \\
\text { Percent }\end{array}$ & \\
\hline Male & 225 & 64.5 & 64.5 & 64.5 \\
\hline Female & 124 & 35.5 & 35.5 & 100.0 \\
\hline \multirow[t]{4}{*}{ Total } & 349 & 100.0 & 100.0 & \\
\hline & \multicolumn{3}{|c|}{ Age } & \\
\hline & Frequency & Percent & Valid & Cumulative \\
\hline & & & Percent & Percent \\
\hline $15-25$ & 154 & 44.1 & 44.1 & 44.1 \\
\hline $26-35$ & 123 & 35.2 & 35.2 & 79.4 \\
\hline $36-45$ & 54 & 15.5 & 15.5 & 94.8 \\
\hline $46-55$ & 11 & 3.2 & 3.2 & 98.0 \\
\hline 56-above & 7 & 2.0 & 2.0 & 100.0 \\
\hline Total & 349 & 100.0 & 100.0 & \\
\hline
\end{tabular}

\section{Exploratory Factor Analysis}

Factor analysis test was applied to all the scales measured in the study. It has been observed that KMO values of all components used in the study are greater than 0.70 . Furthermore, Bartlett's Test of Sphericity of all the components showing significant values at 0.05 level. Factor analysis also show "rotated component matrix" which is a matrix of the factor loadings for each variable onto each factor. In other words, "rotated component matrix shows which questions relates to which factor" (Crezee, 2009). Table 2 displays high loading of greater than 0.5 of all the items in their respective components (variables).

Table 2: Rotated Component Matrix

\begin{tabular}{|c|c|c|c|c|}
\hline & $\mathrm{SP}$ & $\mathrm{CC}$ & $\begin{array}{l}\mathrm{AC} \\
(\mathrm{PA})\end{array}$ & $\begin{array}{l}\mathrm{AC} \\
(\mathrm{NA}) \\
\end{array}$ \\
\hline "The salaries are package adequate for my level". & .981 & & & \\
\hline $\begin{array}{l}\text { "The salary and other variable payments compare well with the rest } \\
\text { of the market". }\end{array}$ & .984 & & & \\
\hline "The remuneration package is attractive". & .976 & & & \\
\hline "My remuneration matches my efforts in my job". & .970 & & & \\
\hline "The rewards the firm gives motivates one for better performance". & .963 & & & \\
\hline "There are incentives for good performance". & .965 & & & \\
\hline "I perceive the reward system to be equitable". & .613 & & & \\
\hline "Rewards given for good performance are valuable". & .988 & & & \\
\hline "In most ways my life is close to my ideal". & & .760 & & \\
\hline "The conditions of my life are excellent". & & .832 & & \\
\hline
\end{tabular}


Nimra Ali Khokher \& Abdul Raziq / The Relationship between Salary Packages and Employee's Subjective Well-

being: Evidence from Service-based SMEs in Pakistan

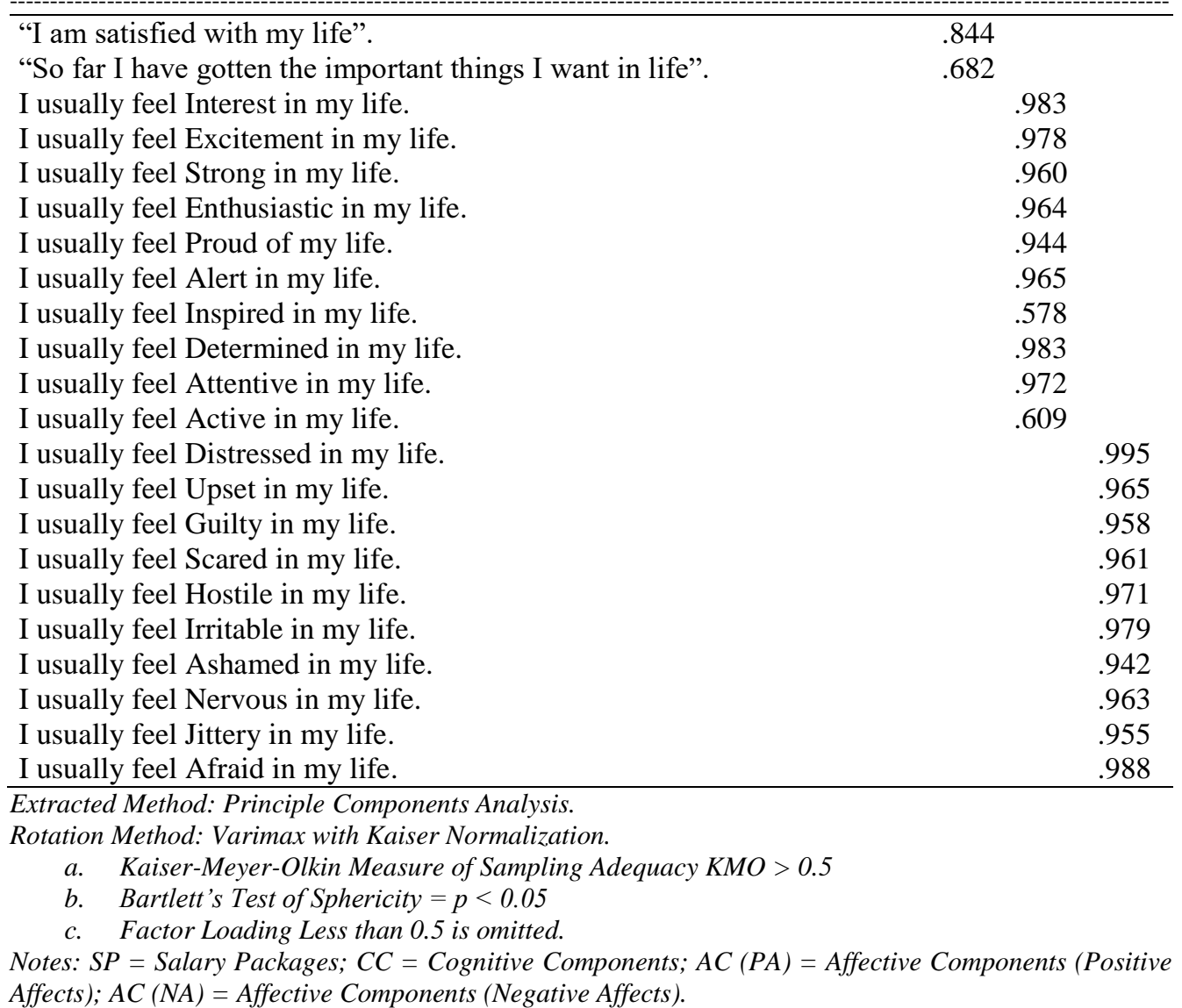

\section{Correlation}

Before performing regression analysis for testing the hypotheses, the correlation between variables should be examined. According to (Hair, Black, Babin, \& Anderson, 2010), if variables are correlated with each other, it is suitable to proceed forward for testing the hypotheses to investigate the impact of salary packages upon employee's SWB through regression analysis. Table 3 indicates that there exist correlation between all the variables used in the study. Therefore, it is feasible to run regression analysis for testing the hypotheses. However, results also indicate that among all variables, negative affects variable of affective components of the employee's SWB is not showing significant correlation with other variables of the study. Thus, they are discarded in further analysis. 
Nimra Ali Khokher \& Abdul Raziq / The Relationship between Salary Packages and Employee's Subjective Well-

Table 3: Reliability Analysis and Correlations

\begin{tabular}{lllll}
\hline & SP & AC(PA) & AC(NA) & CC \\
\hline SP & $(0.977)$ & & & \\
AC(PA) & $.354^{* *}$ & $(0.973)$ & & \\
AC(NA) & -.061 & -.033 & $(0.992)$ & \\
CC & $.421^{* *}$ & $.342^{* *}$ & -.008 & $(0.764)$
\end{tabular}

** Correlation is significant at the 0.05 level (2-tailed).

Cronbach Alpha Coefficients for multi item scales are listed on the diagonal in parentheses.

Notes: $S P=$ Salary Packages; $C C=$ Cognitive Components; $A C(P A)=$ Affective Components (Positive Affects); AC (NA) = Affective Components (Negative Affects).

\section{Regression Analysis}

Regression analysis was performed in order to test the hypotheses to study the impact of salary packages upon employee's SWB. Two Hypotheses developed by this study are being tested. Before testing the hypotheses, basic assumptions of regression analysis were addressed (see appendix A).

H1: There is a significant positive relationship between salary packages and affective components of employee's subjective well-being.

This study tests the hypotheses to study the relationship between salary packages (SP) and affective components of employee are SWB. Table 4 displays R square (0.126) and adjusted $\mathrm{R}$ square $(0.123)$ values, indicating that about $12 \%$ variance is explained by salary packages (SP) in positive effects (PA) of affective components of employee's SWB. "Multiple correlation coefficient" of $\mathrm{R}=0.354$ is significant $(\mathrm{F}(349)=49.874$; $\mathrm{p}<0.05$ ). The $\mathrm{p}$ value is less than 0.05 . Results postulated that salary packages (SP) show significant positive variance in positive affects (PA) of affective components of employee's SWB.

Table 4: Regression of salary packages upon affective components

\begin{tabular}{llllll}
\hline $\mathrm{R}$ & $\mathrm{R}$ Square & $\begin{array}{l}\text { Adjusted R } \\
\text { Square }\end{array}$ & $\begin{array}{l}\text { Std. Error of } \\
\text { the Estimate }\end{array}$ & $\mathrm{F}$ & Sig \\
\hline $.354^{\mathrm{a}}$ & .126 & .123 & 1.03993 & 49.874 & .000 \\
\cline { 2 - 6 } & $\begin{array}{l}\text { Unstandardized } \\
\text { Coefficients }\end{array}$ & $\begin{array}{l}\text { Standardized } \\
\text { Coefficients }\end{array}$ & $\mathrm{t}$ & Sig. \\
\cline { 2 - 6 } & $\mathrm{B}$ & Std. Error & Beta & & \\
\cline { 2 - 6 }$($ Constant $)$ & 2.795 & .099 & & 28.222 & .000 \\
SP & .793 & .112 & .354 & 7.062 & .000 \\
\hline
\end{tabular}

a. Predictors: (Constant), $S P=$ Salary Packages.

b. Dependent Variable: PA = Positive Effects of Affective Components of SWB 
Nimra Ali Khokher \& Abdul Raziq / The Relationship between Salary Packages and Employee's Subjective Well-

Table 4 indicates that beta $=0.354$ is significant $(\mathrm{t}(349)=7.062 ; \mathrm{p}<0.05)$. Results represent the contribution of salary packages (SP) along with other variables, in determining the positive effects (PA) of affective components of employee's SWB. This shows that salary packages (SP) have a significant positive impact upon the positive emotions, feelings of the employees.

H2: There is a significant positive relationship between salary packages and cognitive components of employee's subjective well-being.

Moreover, the results of regression analysis of the study test the hypotheses to investigate the relationship between salary packages (SP) and cognitive components (CC) of employee's SWB. Table 5 displays R square (0.178) and adjusted R square (0.175) values, indicating that about $18 \%$ variance is explained by salary packages (SP) in cognitive components (CC) of employee's SWB. "Multiple correlation coefficient" of $R=0.421$ is significant $(F(349)=79.954 ; p<0.05)$. The $p$ value is less than 0.05 . Thus, the results of the study demonstrated that salary packages (SP) show significant positive variance in cognitive components (CC) of employee's SWB.

Table 5: Regression of salary packages upon Cognitive components

\begin{tabular}{llllll}
\hline $\mathrm{R}$ & $\mathrm{R}$ Square & $\begin{array}{l}\text { Adjusted R } \\
\text { Square }\end{array}$ & $\begin{array}{l}\text { Std. Error of } \\
\text { the Estimate }\end{array}$ & $\mathrm{F}$ & $\mathrm{Sig}$ \\
\hline $.421^{\mathrm{a}}$ & .178 & .175 & .61423 & 79.954 & .000 \\
\cline { 2 - 6 } & $\begin{array}{l}\text { Unstandardized } \\
\text { Coefficients }\end{array}$ & $\begin{array}{l}\text { Standardized } \\
\text { Coefficients }\end{array}$ & $\mathrm{t}$ & $\mathrm{S}$ Sig. \\
\cline { 2 - 6 } & $\mathrm{B}$ & Std. Error & Beta & & \\
\cline { 2 - 6 } (Constant) & 1.997 & .058 & & 34.139 & .000 \\
SP & .574 & .066 & .421 & 8.658 & .000 \\
\hline
\end{tabular}

a. Predictors: (Constant), $S P=$ Salary Packages.

b. Dependent Variable: $C C=$ Cognitive Components of $S W B$

\section{Discussion}

This study has aimed to investigate the relationship between salary packages and employee's SWB. The analysis of results for this study indicated that salary packages is correlated with the affective and cognitive components of employee's SWB. Moreover, if the literature of the study is observed, it seems that employee's SWB has two parts (cognitive components and affective components). However, affective components are the combination of positive and negative affection (Shmotkin, 1998). Here positive affection means pleasant emotions or feeling like happiness or joy and negative affection means unpleasant emotions or feelings like sadness or anger and at one time. A person may have either pleasant emotions, feelings or he may have unpleasant emotions, feelings (Page, 2005). 
Nimra Ali Khokher \& Abdul Raziq / The Relationship between Salary Packages and Employee's Subjective Well-

It means that in case of affective components of employee's SWB, a person may have only positive affection of affective components or have only negative affections of affective components. Similarly, the results of correlations support the literatures by showing significant correlation with positive association salary packages with affective components and cognitive components of employee's SWB. However, results indicated insignificant correlation with negative effects of affective components of employee's SWB. Thus, negative effects of affective components of employee's SWB are discarded for further analysis. Therefore, the data of the study was suitable to proceed further to test the hypotheses by considering the positive effects of effective components and cognitive components of employee's SWB in order to investigate the impact of salary packages upon employee's SWB through regression analysis (Hair et al., 2010).

After testing the hypotheses it is revealed that significant positive contribution has been determined by salary packages in predicting the affective components as well as cognitive components of employee's SWB. In this way, results of the study postulated that there is a significant positive impact of salary packages upon affective components of employee's SWB as well as significant positive impact of salary packages upon cognitive components of employee's SWB.

In this way, our results support the literature that when attractive and competitive salary packages are given to employees then employees becomes more committed to the organization. Therefore, an attractive salary package has the potential to increase the positive feelings and behaviors of the talented people of the organization (Kirkland, 2009). It has also been observed that when attractive salary packages are given to the deserving talent, they are encouraged and satisfied to work hard and become motivated to their work (Coetsee, 2011). Therefore, it seems to be very important for the organizations to setup such kind of salary structure which boost the positive feelings, behaviors and satisfactions of the employees (Coetsee, 2011). Moreover, Coetsee (2011) suggested that top management of the organization should make struggle in order to motivate and encourage their talented people of the organization and then provide such recognition to the employees, which can appreciate the employees in order to perform well for the success of the organization. Therefore, such excellent and attractive salary packages bring positivity in the feelings, behaviors and in the satisfaction of the talented people in the organization. Hence, SWB is the combination of positive and negative affection and life satisfaction (Shmotkin, 1998). Similarly, "SWB involves a multidimensional evaluation of life, including cognitive judgments of life satisfaction and affective evaluations of emotions and moods" (McGillivray \& Clarke, 2006). This indicates that a valuable system of salary fosters the affective and cognitive aspects of employee's SWB.

Sukkur IBA Journal of Management and Business | Volume 4 No. 1 January - June 2017 @ Sukkur IBA University 
Nimra Ali Khokher \& Abdul Raziq / The Relationship between Salary Packages and Employee's Subjective Well-

being: Evidence from Service-based SMEs in Pakistan

\section{Conclusion}

This study examine the relationship between salary packages and employee's SWB of service based SMEs in Pakistan. After testing the hypotheses, our study indicated that the practice of salary packages plays a vital role in shaping the SWB of employees. Hence, our study concluded that salary packages have significant positive impact upon affective and cognitive components of employee's SWB.

Our study indicates that when an organization implements practice of excellent and attractive salary packages, such practices develop a realization of trust among the employees which bring positivity in their feelings and behaviors and this will develop their belonging and satisfaction towards the organization supporting that there is a significant positive impact of salary packages upon SWB of the employees.

It is the responsibility of the top management of an organization to pay due care and due diligence while implementing the practice of excellent and attractive salary packages in the organization because the success or failure of an organization is dependent upon the strategies of managing the talent who are the most important assets and whose satisfaction and engagement determine the effectiveness of the organization.

Management of the organization should make struggle in order to search that by which ways, they can motivates and encourage their talented people of the organization and then provide such recognition to the employees, which can appreciate the employees in order to perform well for the success of the organization.

Our study has some limitations. This study could not collect the data from the manufacturing sector SMEs of Quetta, due to lack of large number of manufacturing units. Our study could not target the SMEs of other cities of Pakistan due to limited access, time constraint and inconvenience. Therefore, it is recommended that future researcher should emphasize their study by considering SMEs operating in other parts of the country.

The findings of this study will be fruitful for theoretical development, because very few studies have been conducted in SMEs regarding salary packages and SWB. Hence, in the literary studies, there is a huge gap with regard to SMEs. Therefore, this study will be an addition as a new knowledge in the literature of SMEs. This study will be beneficial for the HR practitioners of SMEs, as they become aware that how critical the management and development of the people for an organization. The study will also be helpful for other researchers, as they will get guidelines from the findings of this research and will be able to undergone more studies in this area.

Sukkur IBA Journal of Management and Business | Volume 4 No. 1 January - June 2017 @ Sukkur IBA University 
Nimra Ali Khokher \& Abdul Raziq / The Relationship between Salary Packages and Employee's Subjective Well-

being: Evidence from Service-based SMEs in Pakistan

\section{References}

Ben-Zur, H. (2003). Happy adolescents: The link between subjective well-being, internal resources, and parental factors. Journal of Youth and Adolescence, 32(2), 67-79.

Bouri, A., Breij, M., Diop, M., Kempner, R., Klinger, B., \& Stevenson, K. (2011). Report on support to SMEs in developing countries through financial intermediaries. Dalberg, November.

Calice, P., Chando, V. M., \& Sekioua, S. (2012). Bank financing to small and medium enterprises in east Africa: findings of a survey in Kenya, Tanzania, Uganda and Zambia.

Chikumbi, C. N. L. (2011). An investigation of talent management and staff retention at the bank of Zambia.

Coetsee, L. D. (2011). Peak performance and productivity: a practical guide for the creation of a motivating climate: Andcork Publishers.

Collings, D. G., \& Mellahi, K. (2009). Strategic talent management: A review and research agenda. Human resource management review, 19(4), 304-313.

Crezee, C.-J. (2009). 'What are the Success Factors of an Effective Service Brand Policy and how Can Dutch Health Care Companies, Ie Hospitals, Use Segmentation to Build a Strong Brand?': Erasmus University.

DDPQ, (2011). Planning \& Development Department. Government of Balochistan in collaboration with UNICEF.

Dhulla, T. V. (2013). To study the talent management system in banking sector with regards to motivation \& satisfaction.

Diener, E. (1994). Assessing subjective well-being: Progress and opportunities. Social indicators research, 31(2), 103-157.

Eikebrokk, T. R., \& Olsen, D. H. (2007). An empirical investigation of competency factors affecting e-business success in European SMEs. Information \& Management, 44(4), 364-383.

Hair, J., Black, W., Babin, B., \& Anderson, R. (2010). Multivariate Data Analysis Seventh Edition Prentice Hall.

Jansen, R.C.(2008). An investiogation into the SWB of the female stripper (MS Thesis), University of South Africa.

Kirkland, S. D. (2009). Compensation plans that pay back. Business and Economic Review, 55(2), 22-23.

Locke, E. A. latham GP. 1990. A Theory of Goal Setting and Task Performance. Englewood Cliffs.

Lockwood, T., \& Walton, T. (2008). Building design strategy. Using Design to Achieve Key Business.

McGillivray, M., \& Clarke, M. (2006). Human well-being: Concepts and measures. Understanding human well-being, 3-16.

Page, K. (2005). Subjective wellbeing in the workplace. Unpublished honours thesis, Deakin University, Melbourne, Australia.

Sukkur IBA Journal of Management and Business | Volume 4 No. 1 January - June 2017 @ Sukkur IBA University 
Nimra Ali Khokher \& Abdul Raziq / The Relationship between Salary Packages and Employee's Subjective Well-

being: Evidence from Service-based SMEs in Pakistan

Raziq, A., \& Shaikh, A. A. (2015). Exploring recruitment \& selection practices in Pakistani SMEs. International Journal of Basic and Applied Sciences, 4(1), 102.

Shmotkin, D. (1998). Declarative and differential aspects of subjective well-being and its implications for mental health in later life Handbook of aging and mental health (pp. 15-43): Springer.

Van Hoorn, A. (2007). A short introduction to subjective well-being: Its measurement, correlates and policy uses.

Westaway, M. S., \& Maluka, C. S. (2005). Are life satisfaction and self-esteem distinct constructs? A black South African perspective. Psychological reports, 97(2), 567-575.

Sukkur IBA Journal of Management and Business | Volume 4 No. 1 January - June 2017 @ Sukkur IBA University 
Nimra Ali Khokher \& Abdul Raziq / The Relationship between Salary Packages and Employee's Subjective Well-

being: Evidence from Service-based SMEs in Pakistan

\section{Appendix A: Assumptions of Multiple Regression Analysis}

\section{Linearity}

It is argued in prior studies that the assumption of linearity is most important for regression analysis because all the results of the analysis based upon the linearity (Keith, 2006). Therefore, if there is no linear relationship between dependent and independent variables then the true relationship will be under or over estimated by the results of the regression analysis (Osborne \& Waters, 2002). Figure 01 indicates linear relationship between dependent and independent variables. Therefore, the data used for this satisfied the assumption of linearity. Hence, assumption of linearity is not violated.

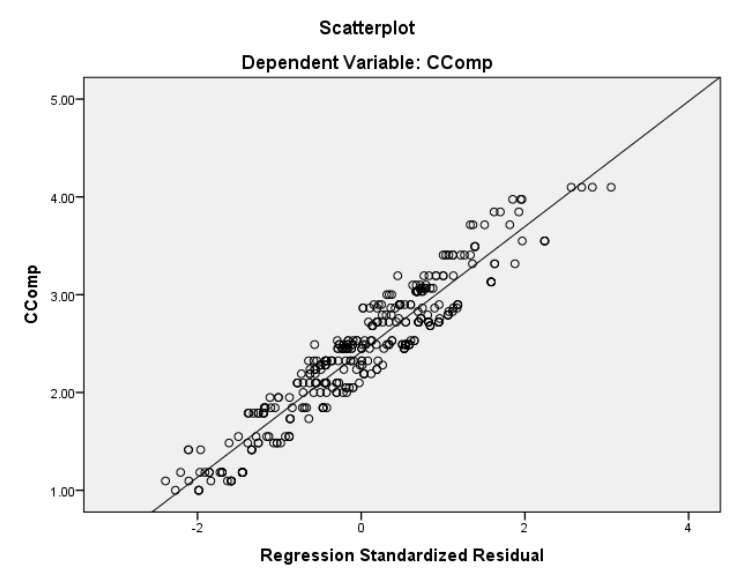

Figure 1: Linearity

\section{Normality}

For regression analysis, data should be normally distributed (Hair et al. 2010). Normality can be checked through different methods such as, through skewness, kurtosis statistic table, histograms and P-plot (Osborne \& Waters, 2002). Table 6 indicates normal distribution of the data used in the study through skewness and kurtosis statistic table. Figure 02 displays a histogram which is a bar graph showing a curve which is representing normal distribution of the data. Similarly, figure 03 displays Pplot which is also representing normal distribution of the data used in the study. All these show normal distribution of the errors, and the plot of the residuals values is a normal curve. Therefore, assumption of normality is not violated. 
Nimra Ali Khokher \& Abdul Raziq / The Relationship between Salary Packages and Employee's Subjective Wellbeing: Evidence from Service-based SMEs in Pakistan

Table 6: Normality of the Data $(n=349)$

\begin{tabular}{crrrrrr}
\hline & Mean & Std. Deviation & \multicolumn{2}{c}{ Skewness } & \multicolumn{2}{c}{ Kurtosis } \\
\cline { 2 - 7 } & \multicolumn{3}{c}{ Statistic } & Std. Error & Statistic & Std. Error \\
\cline { 2 - 7 } SP & 0.7294 & .49639 & .254 & .131 & -1.317 & .260 \\
CC & 2.4159 & .67635 & -.030 & .131 & -.183 & .260 \\
AC (PA) & 3.3736 & 1.11056 & -.159 & .131 & .159 & .260 \\
AC (NA) & 23.6126 & 10.51699 & .258 & .131 & -.982 & .260 \\
\hline
\end{tabular}

Notes: SP = Salary Packages; $C C=$ Cognitive Components; $A C(P A)=$ Affective Components (Positive Affects); AC (NA) = Affective Components (Negative Affects).

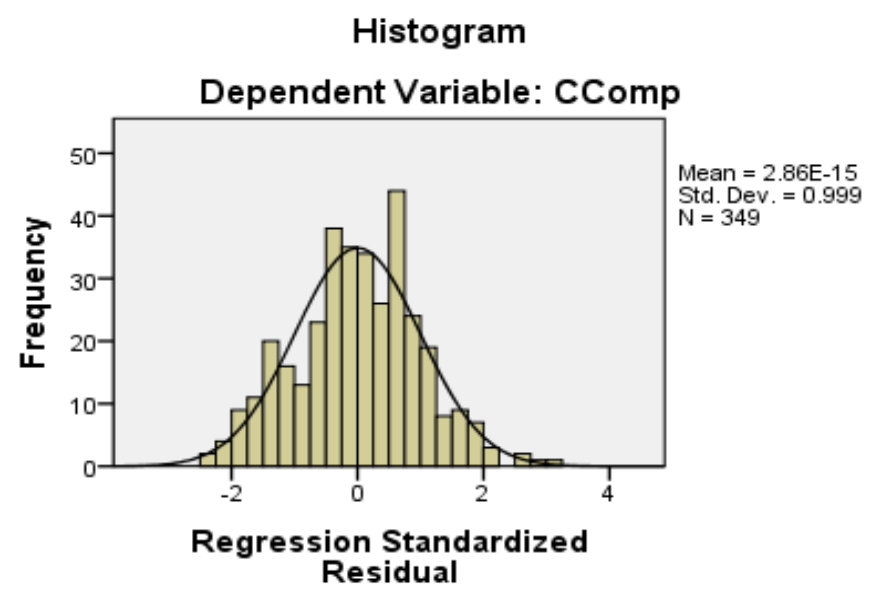

Figure 2: Histogram for Normality

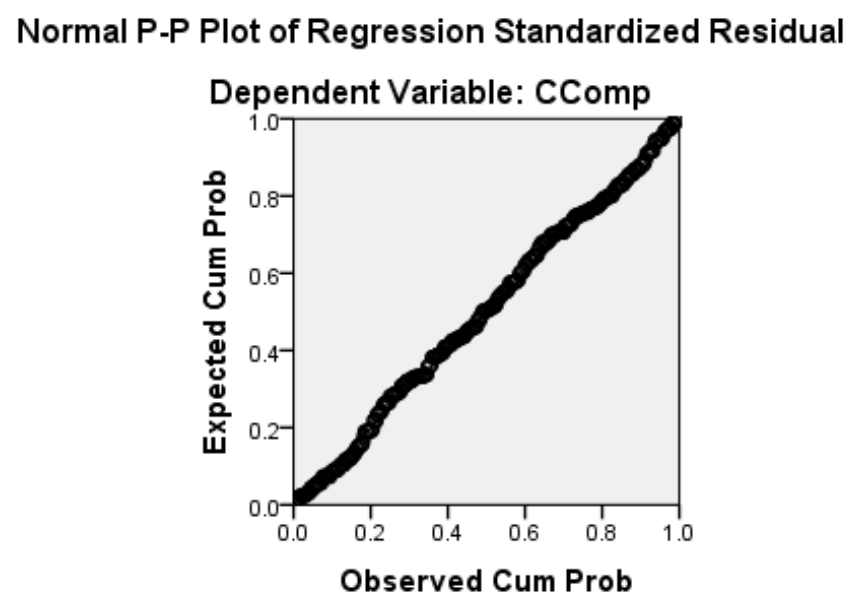

Figure 3: P-plot for Normality 
Nimra Ali Khokher \& Abdul Raziq / The Relationship between Salary Packages and Employee's Subjective Well-

being: Evidence from Service-based SMEs in Pakistan

(pp. 64-81)

\section{Homoscedasticity}

For regression analysis, the assumption of homoscedasticity should be satisfied. Homoscedasticity is showing "equal variance of errors across all levels of the independent variables" (Osborne \& Waters, 2002). Therefore, "errors are spread out consistently between the variables" (Keith, 2006). Figure 04 support the literatures and indicates that "errors are spread out consistently between the variables". Therefore, the assumption of homoscedasticity is not violated by the data used in this study.

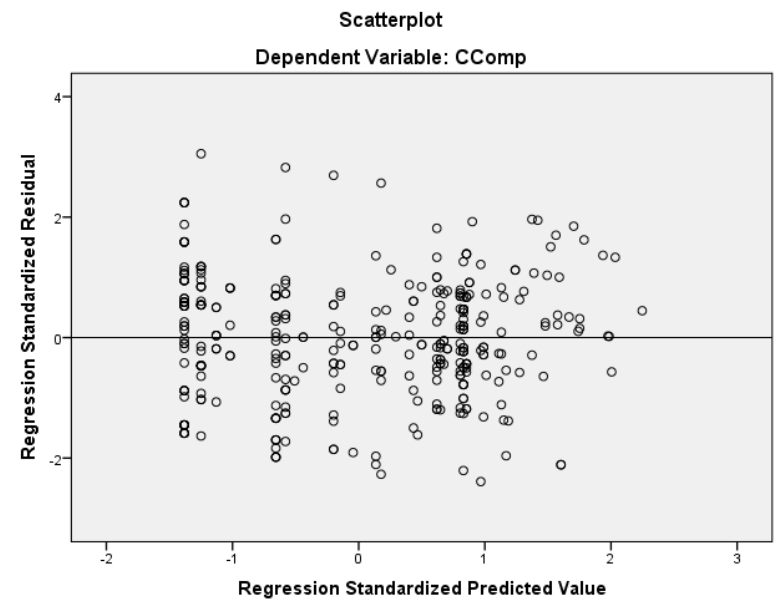

Figure 4: Homoscedasticity 